\title{
In Vitro Mass Multiplication of Anthurium andreanum (HORT) Cultivars
}

\author{
D.P. Prakasha ${ }^{1 *}$, G. Ramya ${ }^{2}$ and G.B. Srinivasalu ${ }^{1}$ \\ ${ }^{1}$ College of Horticulture, Munirabad, Koppal-583 233, Karnataka, India \\ ${ }^{2}$ Meghana Tissue Culture Nursery, Davanagere, Belavanuru Post-577104, Karnataka, India \\ *Corresponding author
}

\begin{tabular}{|c|c|}
\hline & A B S T R A C T \\
\hline & \multirow{6}{*}{ 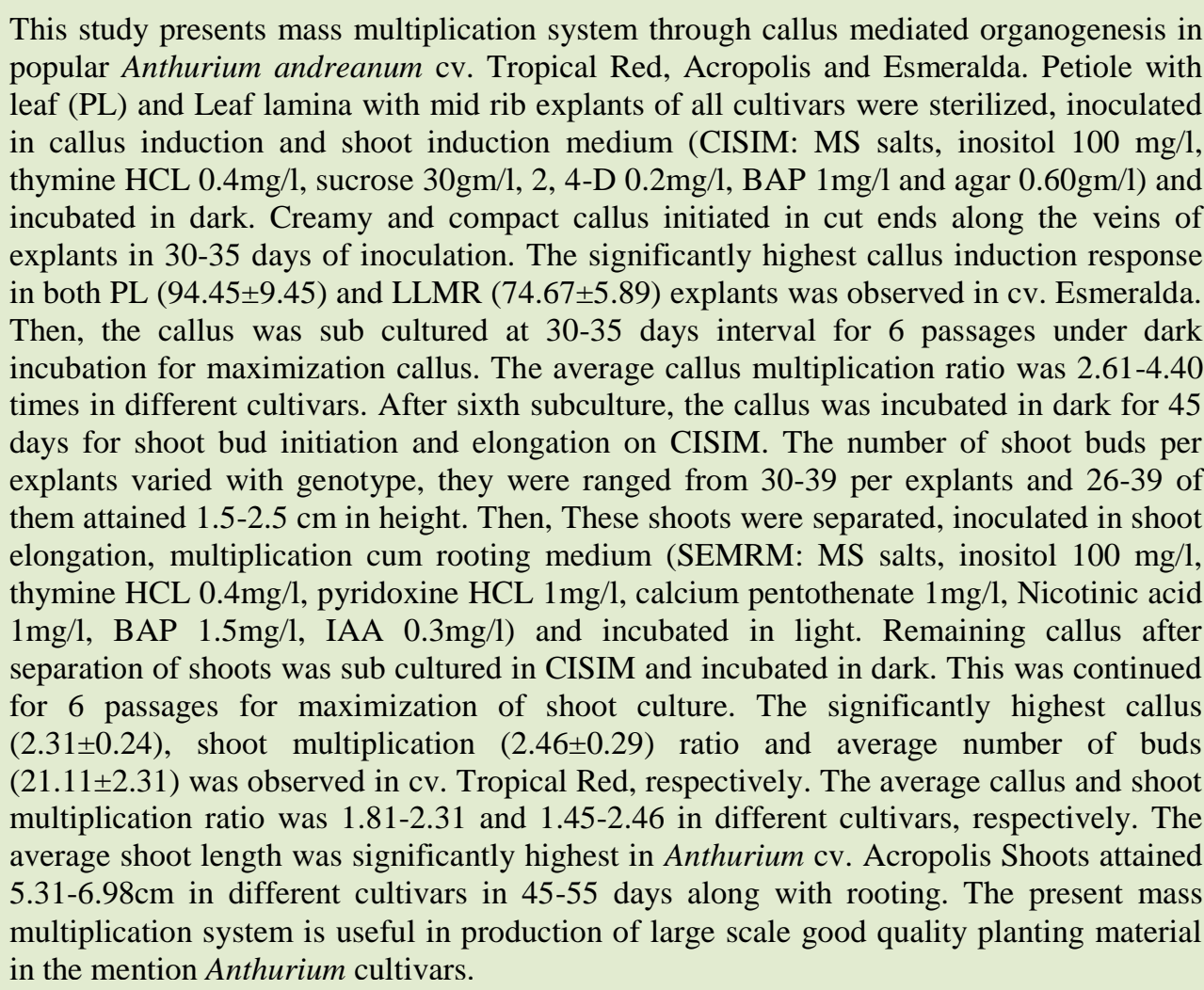 } \\
\hline Keywords & \\
\hline $\begin{array}{l}\text { Tropical Red, } \\
\text { Acropolis, } \\
\text { Esmeralda, Leaf } \\
\text { lamina explants, } \\
\text { Dark incubation. }\end{array}$ & \\
\hline Article Info & \\
\hline $\begin{array}{l}\text { Accepted: } \\
26 \text { August } 2017 \\
\text { Available Online: } \\
\text { 10 September } 2017\end{array}$ & \\
\hline & \\
\hline
\end{tabular}

\section{Introduction}

Anthurium is a highly prized perennial herb and major cut flower species belongs to economically important genera in the family Araceae. It is cultivated in the tropical and subtropical countries. Among several spices, only two are popular for their attractive long lasting flowers. In the global market, it is a high value crop with high productivity and profit per unit area. However, availability of quality planting material is essential for commercial cultivation of such market conscious flower crops. The three basic 
propagation methods for Anthurium, propagation by seed, traditional vegetative and tissue culture are used for conventional production. Tissue culture offers an alternative tool for rapid multiplication quality planting material in short period. In vitro plant propagation in Anthurium has been achieved by using various tissues including leaf, petiole, spadix, spathe, seed, lateral bud and shoot tips through direct and indirect organogenesis (Atak and Celik, 2009) and this technique is commercially used (Martin et al., 2003) for production of planting material. Further, various physical and biological factors including media play role during Anthurium micro propagation (Silva et al., 2005; Bejoy et al., 2008) and one of the important factors among them was genotype. However, reports on reliable mass multiplication system through long term in vitro culture and commercially viable systems are lacking. In this view, this paper presents an in vitro mass multiplication system in Anthurium andraeanum (Hort) cultivars Tropical Red, Acropolis and Esmeralda, developed through researching responses of cultures during long term in vitro subculture for large scale multiplication of both callus and shoots.

\section{Materials and Methods}

\section{Media preparation and sterilization}

Media compositions for callus induction, multiplication and shoot induction; shoot elongation, multiplication and rooting were standardized through studies conducted in our laboratory. The callus induction, multiplication and shoot initiation medium (CISIM) was prepared by mixing MS salts (Murashige and Skoog, 1962) inositol 100 $\mathrm{mg} / \mathrm{l}$, Thymine $\mathrm{Hcl} 0.4 \mathrm{mg} / \mathrm{l}, 30 \mathrm{gm} / \mathrm{l}$ sucrose, $0.2 \mathrm{gm} / 1$ 2,4-D and $1 \mathrm{mg} / \mathrm{l} \mathrm{BAP}$. The $\mathrm{pH}$ of the medium was adjusted to $5.8 \pm 0.1$ using $1 \mathrm{M}$ $\mathrm{NaOH}$ or HCL and solidified with $6.5 \mathrm{gm} / 1$ agar before autoclaving. The shoot elongation, Multiplication and rooting medium (SEMRM) was prepared by mixing MS salts, $100 \mathrm{mg} / \mathrm{l}$ inositol, $0.4 \mathrm{mg} / \mathrm{l}$ thymine HCL, 1mg/l pyridoxine HCL, 1mg/l calcium pentothenate, $1 \mathrm{mg} / \mathrm{l}$ Nicotinic acid, $1.5 \mathrm{mg} / \mathrm{l}$ BAP, and $0.3 \mathrm{mg} / \mathrm{l}$ IAA. The $\mathrm{pH}$ of the medium was adjusted to $5.8 \pm 0.1$ using $1 \mathrm{M}$ $\mathrm{NaOH}$ or HCL and solidified with, boiled with $6.5 \mathrm{gm} / \mathrm{l}$ agar, dispensed $30-35 \mathrm{ml}$ into pre sterilized $250 \mathrm{ml}$ glass culture bottles. Bottles containing media were autoclaved in steam sterilizer (Nat steel Pvt. Ltd., India) at $121{ }^{\circ} \mathrm{C}$ and $15 \mathrm{lbs}$ for 18 minutes and stored in media storage room at ambient temperature for 7-10 days before usage.

\section{Explants collection, sterilization, inoculation and incubation}

Selection of elite mother plant and a disease and pest free young leaf with greenish tinge was excised from mother plant, Immediately dipped leaf stalk into sterile water and brought to laboratory, it was washed two times in sterile water for 15 minutes, immersed in Baiting $200 \mathrm{mg} / 100 \mathrm{ml}$ and citified $50 \mathrm{mg} / 100 \mathrm{ml}$ with 2 drop soap oil tween-20, kept in shaker for 1 hour, water washes 3-4 times. Then explants were immersed in $2 \%$ sodium hypochlorite for four minutes, washed for two minutes in sterile water and this step was repeated, changed the flask, $0.01 \%$ mercuric chloride for five minutes, 4 times sterile water washes at three minutes interval. $70 \%$ ethanol dip for 30 seconds, two sterile water washes at 2 minutes interval, excised into shoot tip, petiole and mid rib with $0.5 \mathrm{~cm}$ leaf lamina both side, inoculate into callus induction medium and incubated in dark conditions at $25 \pm 1^{\circ} \mathrm{C}$ (Prakasha et al., 2017)

\section{Subculture for callus maximization}

Callus was separated from initiated cultures, five callus clumps of $\sim 0.5 \mathrm{~cm}^{2}$ size has been inoculated in a bottle and incubated at $25 \pm 1^{\circ} \mathrm{C}$ 
in dark conditions. Seven subcultures at 30-35 days interval were taken up for callus multiplication.

\section{Subculture for shoot elongation and rooting}

Seventh subcultured callus cultures were incubated for 45 days for shoot bud initiation. Shoots of $>1.5 \mathrm{~cm}$ with a $2-3 \mathrm{~mm}$ callus at base were separated, eight shoots were inoculated per bottle containing shoot elongation and rooting medium and incubated in light conditions at $25 \pm 1^{\circ} \mathrm{C}$. After shoot separation, remaining callus clumps were inoculated in callus multiplication medium and incubated in dark at $25 \pm 1^{\circ} \mathrm{C}$. The culture bottles carrying the explants on semi-solid media was arranged in culture rack in the growth room.

\section{Data collection and statistical analysis}

Observations on callus induction in callus induction and multiplication medium were recorded after four weeks of inoculation. Observations on shoot bud induction and elongation in callus induction and multiplication medium recorded after six weeks of inoculation. Observations on shoot elongation were recorded after seven weeks on inoculation. All experiments were repeated for several times over years and data presented from five times with 5 replications. The data was subject to ANOVA for finding significance in observations. The results are presented as either percentage \pm standard errors or average \pm standard errors.

\section{Results and Discussion}

Micropropagation is an alternative method of vegetative propagation, which is well-suited for the multiplication of elite clones (Silva et al., 2005). In this study, an in vitro mass multiplication system has been presented for three Anthurium andraeanum cultivars viz.,
Tropical Red (Figure 1), Acropolis and Esmeralda.

In this study, creamy and compact callus formation of was observed on explants after 30-35 days of initiation in Petiole with leaf (PL) and 40-45 days in leaf lamina with mid rib (LLMR). It took another 20-25 days after callus initiation for first subculture as callus growth in them was little slow compared to subsequent subcultures. The results revealed that callus induction, average callus multiplication ratio and number of shoot buds per bottle were significantly in different cultivars (Table 1). The petiole with leaf (PL) showed higher callus induction in all three cultivars compared to leaf lamina with mid rib explants (LLMR). The Anthurium Cv. Esmeralda showed significantly highest callus induction in both PL $(94.45 \pm 9.45)$ and LLMR explants $(74.67 \pm 5.89)$ compared to other varieties. The success of tissue culture is related to the correct choice of explants material (George et al., 2008). Prakash et al., (2017), has reported that the explants of leaf lamina segments and petiole with leaf of different stage of growth (brown and green) showed different morphogenetic responses in vitro during indirect organogenesis in the same cultivars of Anthurium. Further, they reported that the explants from green leaf stage showed early and high callus induction in the same cultivars of Anthurium. In this study green leaf has been used as starting material and achieved similar kind of results mentioned by them.

In this study, the average callus induction ratio was significantly highest in Anthurium cv. Esmeralda $(4.40 \pm 0.27)$ in six passages for callus maximization. The average callus multiplication ratio ranged from 2.61-4.40 times in different cultivars (Table 1). In earlier studies number of sub cultures was limited to four (Atak and Celik, 2009; Gantait et al., 2008). In this study, subsequently, shoot bud formation and elongation was 
observed in callus cultures incubated in dark for 40-45 days or more in CISIM. The number of shoot buds per explants varied with genotype, they were ranged from 30-39 per explants and 21-25 of them attained 1.5-2.5 $\mathrm{cm}$ in height in dark.

Table.1 Callus induction and multiplication in Anthurium andreanum (Hort.) cultivars on CISIM

\begin{tabular}{|c|c|c|c|c|c|c|c|c|}
\hline $\begin{array}{l}\text { Sl. } \\
\text { No. }\end{array}$ & $\begin{array}{l}\text { Name of } \\
\text { cultivar }\end{array}$ & $\begin{array}{l}\text { No. } \\
\text { Exp } \\
\text { PL }\end{array}$ & $\begin{array}{l}\text { of } \\
\text { LLMR }\end{array}$ & Callus Induc & LLMR & $\begin{array}{l}\text { No. of } \\
\text { bottles }\end{array}$ & $\begin{array}{l}\text { Average callus } \\
\text { multiplication } \\
\text { ratio over seven } \\
\text { sub cultures } \\
\text { (Bottles } \pm \text { SE) }\end{array}$ & $\begin{array}{l}\text { Average No. } \\
\text { of Shoot buds } \\
\text { (mean } \pm \text { SE) }\end{array}$ \\
\hline 1 & Tropical Red & 15 & 60 & $92.34 \pm 8.67$ & $67.74 \pm 8.20$ & 10 & $4.23 \pm 0.24$ & $30.97 \pm 3.24$ \\
\hline 2 & Acropolis & 15 & 60 & $83.94 \pm 6.91$ & $49.42 \pm 7.96$ & 10 & $2.61 \pm 0.19$ & $23.45 \pm 4.12$ \\
\hline 3 & Esmeralda & 15 & 60 & $94.45 \pm 9.45$ & $74.67 \pm 5.89$ & 10 & $4.40 \pm 0.27$ & $39.65 \pm 4.35$ \\
\hline & SEM & & & 3.14 & 2.94 & & 0.14 & 1.58 \\
\hline & $\mathrm{CD}(0.1 \%)$ & & & 7.95 & 7.67 & & 0.39 & 3.54 \\
\hline
\end{tabular}

Note: PL-Petiole with leaf; LLMR-Leaf lamina with mid rib

Table.2 Shoot elongation and rooting in Anthurium andreanum (Hort.) cultivars on SMRM

\begin{tabular}{|c|c|c|c|c|c|c|c|}
\hline \multirow[t]{2}{*}{$\begin{array}{l}\text { Sl. } \\
\text { No. }\end{array}$} & \multirow[t]{2}{*}{ Name of cultivar } & \multirow[t]{2}{*}{ No. of bottles } & \multicolumn{2}{|c|}{$\begin{array}{l}\text { Avg. multiplication rate over } \\
\text { five sub cultures (Bottle } \pm S E \text { ) }\end{array}$} & \multirow{2}{*}{$\begin{array}{l}\text { Avg. no. of } \\
\text { shoots over } 5 \\
\text { sub culture } \\
(\text { No. } \pm \text { SE) }\end{array}$} & \multirow{2}{*}{$\begin{array}{l}\text { Avg. Height } \\
\text { of shoots per } \\
\text { bottle }(\mathrm{cm} \pm \\
\text { SE) }\end{array}$} & \multirow{2}{*}{$\begin{array}{l}\text { Avg. No. } \\
\text { of rooted } \\
\text { plants per } \\
\text { bottle } \\
\text { (nos.) }\end{array}$} \\
\hline & & & Callus & Shoots & & & \\
\hline 1 & Tropical Red & 50 & $2.31 \pm 0.24$ & $2.46 \pm 0.29$ & $21.11 \pm 2.31$ & $5.31 \pm 0.46$ & 8 \\
\hline 2 & Acropolis & 50 & $1.81 \pm 0.21$ & $1.45 \pm 0.18$ & $12.02 \pm 2.19$ & $6.98 \pm 0.51$ & 8 \\
\hline \multirow[t]{3}{*}{3} & Esmeralda & 50 & $2.23 \pm 0.17$ & $2.31 \pm 0.19$ & $18.25 \pm 3.01$ & $6.12 \pm 0.39$ & 8 \\
\hline & SEM & & 0.059 & 0.21 & 1.76 & 0.27 & \\
\hline & $\mathrm{CD}$ & & 1.60 & 0.65 & 7.28 & 0.76 & \\
\hline
\end{tabular}

Fig.1 Mass multiplication of Anthurium andreanum cv. Tropical Red; A) Leaf lamina with mid rib explants cultured on CISIM incubated in dark; B) Maximization of callus CISIM incubated in dark; C) Shooting in SERM incubated in dark; D) Shoot elongation and rooting under light conditions on SERM; E) Primary hardening of plantlets in soil-rite and coco-peat mix (1:1) in polyhouse with controlled conditions; F) Plants ready for sale in plastic covers.
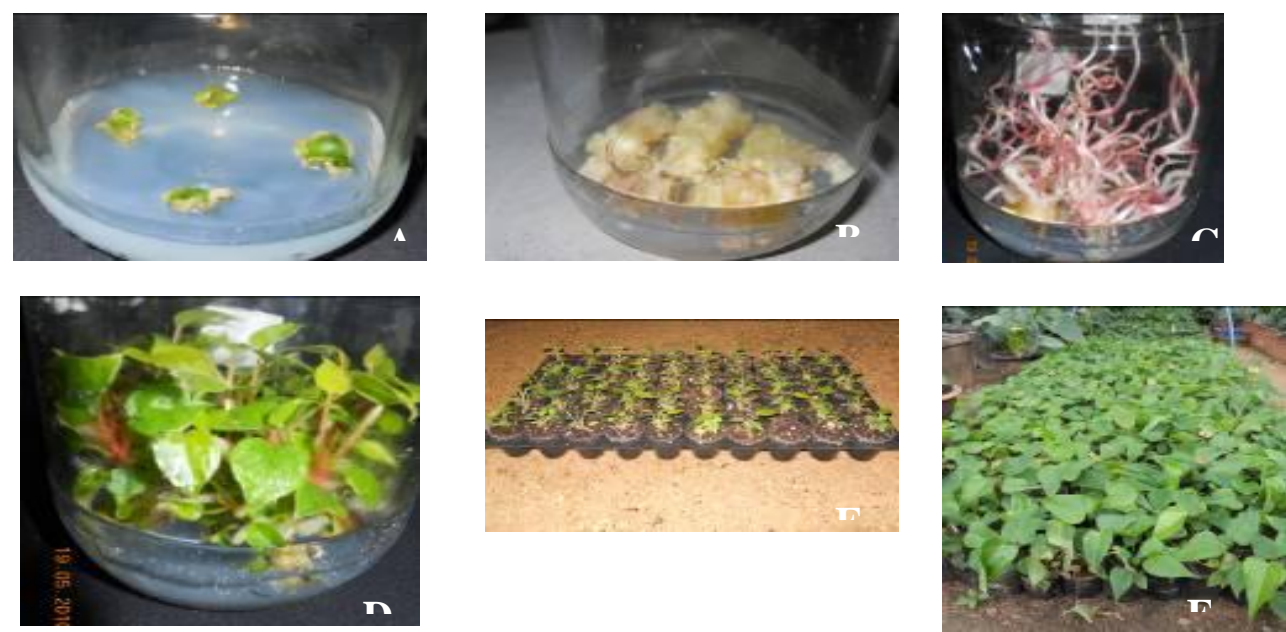
It appears, many factors play an important role during Anthurium In vitro propagation and genotype is the most important factor. In this study, the callus and elongated shoots from these long dark incubated cultures were separated and cultured on CISIM (dark incubation) and SERM (light incubation), respectively for another six passages. The significantly highest average callus $(2.31 \pm 0.24)$ and shoot multiplication $(2.46 \pm 0.29)$ ratio was observed in cv. Tropical Red, respectively. The average callus and shoot multiplication ratio was ranged from 1.81-2.31 and 1.45-2.46 in different cultivars, respectively. The average shoot length was significantly highest $(6.98 \pm 0.51)$ with lowest average number of shoots $(12.02 \pm 2.19)$ in Anthurium cv. Acropolis. On the contrary, the average shoots height was significantly lowest $(5.31 \pm 0.46) \quad$ with highest $(21.11 \pm 2.31)$ number of shoots in Anthurium cv. Tropical Red. The shoots attained $5.31-6.98 \mathrm{~cm}$ in different cultivars in 45-55 days along with rooting in different cultivars. An earlier study reported that genotypes of 10 Anthurium cultivars had different response to callus induction and shoot regeneration Nhut et al., (2006). Our results are in line with earlier report (Atak and Celik, 2009). The reason may be that, many genotype dependent effects are caused by interactions between the plant's genotype and the cultural environment (George, et al., 2008).

The in vitro rooted plantlets were hardened in primary and secondary hardening units. In primary hardening using coco-peat and soilrite mixture (1:1) and misting facilities, 91.93\% of plantlets survived and they are transferred into secondary hardening unit. In the secondary hardening in coir-pith bed under ventilated poly house, $95.63 \%$ of plantlets survived and they were transferred into poly covers. Finally $98.94 \%$ of secondary hardened plantlets survived in pot/cover under shade net.
The present investigation demonstrated a mass multiplication system, which is consistent with responses through several passages in Anthurium cv. Esmeralda, Acropolis and Tropical Red. There was marked difference in morphogentic and organogenetic responses with respect to different type of explants as well as genotype. The suitability of this system is being tested in other popular varieties.

\section{Acknowledgement}

Authors are grateful to Shri. H. S. Shivakumar, Additional Director of Horticulture, Shri. Krishnamoorthy, Joint Director of Horticulture (Biotechnology) and Mr. Y. C. Chandrashekar, ADH, Biocentre, Department of Horticulture, Hulimavu, Bannerughatta road, Bengaluru-560065, Karnataka for encouraging to carryout significant part of the present work. Thanks are also due to Shri. Umapathi and Jayanna, Managing Director of Meghana tissue culture Nursery, Davanagere supporting for carrying out later part of work.

\section{References}

Atak, C., and Celik, O., 2009. Micropropagation of Anthurium from leaf explants. Pak. J. Bot., 41: 1155

Bejoy, M., Sumitha, V. R. and Anish, N. P., 2008. Foliar regeneration in Anthurium andraeanum Hort. cv. Agnihotthri. Biotech. 7: 134

Gantait, S., Mandal, N., Bhattacharyya, S. and Das, P. K., 2008. In vitro Mass Multiplication with Pure Genetic Identity in Anthurium andreanum Lind. Plant Tis. Cult. Biotech. 18: 113.

George, E. F., Hall, M. A. and Klerk, J. D. 2008. Plant propagation by tissue culture, Volume 1. The Background, Springer, pp. 65-75.

Martin, K. P., Joseph, D., Madassery, J. and 
Philip, V. J., 2003. Direct shoot regeneration from lamina explants of two commercial cut flower cltivars of Anthurium andraeanum Hort. In Vitro Cell Developmental Biol.-Plant, 39: 500.

Murashige, T., and Skoog, F., 1962. A revised medium for rapid growth and bioassay with tobacco tissue cultures. Physiol. of Plantarum, 15: 473

Nhut, D.T., Duy, N., Vy, N.N.H., Khue, C.D., Khiem, D.V. and Vinh, D.N., 2006. Impact of Anthurium spp. Genotype on callus induction derived from leaf explants, shot and root regeneration capacity from callus. J. Appl. Hort., 8: 135.

Prakash, D. P., Ramya, G and Srinivasalu, G. B., 2017. Morphogenetic responses in Anthurium andreanum (Hort) cultivars Cur, Agri.Res. J.; 5 (1): 134-140.

Silva, J. A. T., Nagae, S. and Tanaka, M., 2005. Effect of Physical Factors on Micropropagation of Anthurium andraeanum. Plant Tis. Cult, 15(1): 1-6.

\section{How to cite this article:}

Prakasha, D.P., G. Ramya and Srinivasalu, G.B. 2017. In Vitro Mass Multiplication of Anthurium andreanum (HORT) Cultivars. Int.J.Curr.Microbiol.App.Sci. 6(9): 2579-2584.

doi: https://doi.org/10.20546/ijcmas.2017.609.317 